\title{
A revision of Scaphispatha (Araceae - Caladieae) INCLUDING A NEW SPECIES
}

\author{
Eduardo Gomes Gonçalves ${ }^{1}$
}

\begin{abstract}
(A revision of Scaphispatha (Araceae - Caladieae) including a new species) The formerly considered monospecific genus Scaphispatha (Araceae - Caladieae) is here revised. Scaphispatha robusta E.G.Gonç, a second species for the genus is newly described from the Cerrado Biome and the transition CerradoAmazonia. It differs from S. gracilis Brongn. ex Schott by the much more robust petioles and leaves, primary lateral veins drying clearer than the lamina, lateral secondary veins conspicously more prominent than tertiary veins and for the female spadix with 11-15 rows of flowers visible in side view. A key to separate both species is provided, as well as ink illustrations and general remarks on the genus.
\end{abstract}

Key-words: Scaphispatha, Cerrado, Caladieae, Araceae, geophyte.

Resumo

(Revisão de Scaphispatha (Araceae - Caladieae), incluíndo a descrição de uma nova espécie para o gênero) O gênero Scaphispatha (Araceae - Caladieae), até então considerado monoespecífico, é aqui revisado. Scaphispatha robusta E.G.Gonç., uma segunda espécie para o gênero é descrita para o bioma Cerrado e a transição Cerrado-Amazonia. Difere de $S$. gracilis Brongn. ex Schott pelos pecíolos e folhas muito mais robustas, nervuras laterais mais claras que o limbo quando secas, nervuras laterais secundárias mais proeminentes que as terciárias e pela porção feminina do espádice com 11-15 espirais de flores visíveis em vista lateral. Uma chave para separar as espécies, assim como ilustrações em nanquim e aspectos gerais para o gênero são apresentados.

Palavras-chave: Scaphispatha, Cerrado, Caladieae, Araceae, geófita.

\section{INTRODUCTION}

The exclusively neotropical genus Scaphispatha was formerly considered monospecific. The type species - Scaphispatha gracilis - ranges from Brazil to Bolivia (Bogner 1980; Mayo et al. 1997), at the transitional areas between the phytogeographic provinces of the Cerrado, Caatinga and the Amazonia. Despite the wide occurrence, flowering seems to be an ephemeral event, so flowering specimens are very rarely collected. Until living collections were brought to cultivation by Josef Bogner in 1980, only three flowering collections (including the type specimen) were recognized in herbaria (Bogner 1980) and the leaves were unknown.

Recently, a second species of Scaphispatha was recognized when plants from Pará state (Northern Brazil) flowered in cultivation. Sterile specimens of this species has been collected and seen for years, but they were consistently considered as belonging to Caladium because of the large-sized peltate leaves, usually speckled in white.

In order to make easier the comparisons of the newly described species with the former one, both are fully described and illustrated and a taxonomic account for the genus is presented.

\section{Taxonomical Treatment \\ History of the genus}

The genus Scaphispatha was originally described by Heinrich Wilhelm Schott (1860),

Artigo recebido em 05/2005. Aceito para publicação em 08/2005.

${ }^{1}$ Universidade Católica de Brasília. Curso de Ciências Biológicas. Prédio São Gaspar Bertoni - sala M-206, QS-7, Lote 1 - EPTC. CEP 72030-170, Taguatinga - DF - Brazil. Phone: 5561 356-9300

Financial support: Instituto Plantarum de Estudos da Flora Ltda; Biodiversidade do Bioma Cerrado (EMBRAPA, UnB, ISPN, DFID); Fundação Botânica Margaret Mee. 
based on a d'Orbigny specimen deposited the Herbarium of the Paris Museum. He used the name suggested by Adolphe Brongniart in the type sheet. It was placed in the tribe Caladieae, "Subtribus Problematicae". In his Das Pflanzenreich treatment, Engler placed Scaphispatha in the subfamily Aroideae, tribe Zomicarpeae, together with Zomicarpa, Ulearum, Zomicarpella and Xenophia (now Alocasia). The reason for this placement was the presence of a unilocular ovary with basal anatropous ovules.

The genus was reevaluated by Josef Bogner (1980) when new collections from Ceará State, Brazil, were brought into cultivation. These new collections were taken very far from the original locality but a third collection was localized from Pará state. Bogner transferred Scaphispatha to the Englerian subfamily Colocasiodieae, subtribe Caladiineae, based on chromosome numbers and pollen type. This was also the first description of its leaves, which has proven to be peltate. Mayo and collaborators (1997) summarized the current information of this genus in their "The Genera of Araceae", providing detailed illustrations and including it in the tribe Caladieae, with no subtribal recognition. Since then, almost nothing has been published about the genus, except a few ecological remarks (Gonçalves 2004).

\section{Ecology}

Both species of Scaphispatha are true geophytes, producing flowers and leaves during the rainy months and resting leafless during the drier or colder months. Both species occur in well drained soils, but $S$. gracilis seems to prefer drier areas, occuring in open woodland (Cerradão), usually in shaded portions near small ravines. Scaphispatha robusta seems to prefer heavier soils, usually occurring in forest edges or nearby clearings in the forest.

Flowering is usually a short event and fruiting has proven to be even quicker.
Flowering and fruiting are said to occur in 1014 days (Bogner 1980)! Inflorescences in Scaphispatha seem to appear in late October and infructescences are no longer to be found by mid November. Leaves persist a little longer, as long as late February.

\section{Biogeography}

Both species of Scaphispatha have more or less the same general occurrence, ranging across the transition between the Cerrado biome and the Amazonia, with one species in the transition between the Cerrado and the Caatinga biome (dry thorn forest). Both species can be considered sympatric to some extent, but the distributions present different patterns. Scaphispatha gracilis seems to present a wider distribution, ranging from Ceará State to Bolivia, also penetrating deeply in the Cerrado and reaching northern Goiás State. Scaphispatha robusta has a more or less similar distribution, but it seems to penetrate more deeply in the Amazonia, probably occurring in deciduous forms of Amazonian forest, common in Brazilian States of Acre and Rondônia.

\section{Relationships}

Scaphispatha belongs to the tribe Caladieae, together with the economically important genera Xanthosoma, Caladium and Syngonium (Bogner 1980; Mayo et al., 1997). It is not supposed to be especially close to any other genus in the tribe, but Scaphispatha was not surveyed in the only cpDNA phylogenetic analysis of the entire family, performed by French et al. (1995).

Morphologically, Scaphispatha does not have any special aspect that would mark any obvious affinity on it. Vegetatively it looks like a Caladium, with peltate leaves that are sometimes white-speckled. The inflorescence is also of a general type, and the only remarkable aspect is the presence of a unilocular ovary with basal ovules in the female flowers. Other interesting aspect that 
could be considered is the presence of a short but noticeable style. Both features are shared with most genera of the small neotropical tribe Zomicarpeae. In fact, the tribe Zomicarpeae was considered inseparable from Caladieae (French et al. 1995) and some classifications have both groups in an expanded Caladieae (see Keating 2004).

Anyhow, the inclusion of Scaphispatha in a phylogenetic analysis of the entire complex Caladieae-Zomicarpeae would help the clarify which genus or genera are closest to Scaphispatha. A DNA phylogeny of the complex (as well as chromosome counts) has been currently reconstructed by Gonçalves and collaborators and the results will be published further.

Scaphispatha Brongn. ex Schott, Prodr. Syst. Aroid. 214 (1860). Type: S. gracilis Brongn. ex Schott.

Tuberous herb, tuber globose or slightly depressed apically. Leaf usually solitary, occasionally 2-3. Petiole long, marbled, sheath short, inconspicuous. Blade always peltate, ovate-sagittate to ovate-hastate,

primary lateral veins forming a conspicuous collective vein, minor venation reticulate. Inflorescences solitary, appearing much before the leaves or together with them; peduncle from shorter to longer than the petiole. Spathe usually decurrent at base, constriction weak to moderate, tube incompletely convolute. Spadix usually shorter than the spathe, not constricted, densely flowered, fertile male and female zones contiguous or separated by 1-3 rows of sterile male flowers. Flowers unisexual, perigone absent. Male flower 4-6 androus, stamens connate in synandria, with a lateral thecae opening by a slit or a " $T$ " like opening; pollen grains solitary, inaperturate, exine verrucose to subarolate. Female flower with a ovoid to obovoid ovary, 1-locular, ovules $3-7$, anatropous, basally attached by a short funicle; style well developed, connoid, much narrower than the ovary, stigma capitate, slightly broader than the apex of the style. Infrutescence with persistent spathe tube, berries subglobose, one seeded. Testa thin and smooth, endosperm abundant. Chromosomes: $2 \mathrm{n}=28$ (only counted for $S$. gracilis).

\section{Key to the species of Scaphispatha}

Petioles slender, rarely reaching $28 \mathrm{~cm}$ long (usually up to $20 \mathrm{~cm}$ long) and always less than 4 $\mathrm{mm}$ in diameter at base; primary lateral veins drying darker than the lamina; lateral secondary and tertiary veins not significantly different from each other; female part of spadix with 6-9 rows of flowers visible in side view. $S$. gracilis

Petioles robust, never shorter than $28 \mathrm{~cm}$ long in adult plants (usually up to $1 \mathrm{~m}$ long) and always more than $6 \mathrm{~mm}$ in diameter at base, usually more than $1 \mathrm{~cm}$; primary lateral veins drying clearer than the lamina; lateral secondary veins conspicously more prominent than tertiary veins; female part of spadix with 11-15 rows of flowers visible in side view. ... $S$.

Scaphispatha gracilis Brongn. ex Schott, Prodr. Syst. Aroid. 214. 1860. Type: BOLÍVIA. CHIQUITOS. Camiño de San Rafael a Santa Ana, d'Orbigny 1043 (holotype P!, isotype L!). Fig. 1.

Geophytic herb, usually growing in open woodlands (distrophic cerradão) or rocky outcrops, ocasionally in full sunlight.
Stem tuberous, subglobose, $2 \times 3 \mathrm{~cm}$, flesh yellow. Leaf usually solitary, ocasionally $2-$ 4, erect. Petiole smooth, 9-20(-28) × 0.3-0.4 $\mathrm{cm}$, marbled. Blade peltate, cordate to sagittate or subhastate, ovate in outline, membranous, adaxial and abaxial surfaces matte green, somewhat silvery, 9-20 × 6-22 $\mathrm{cm}$, anterior division $5-13 \times 4-13 \mathrm{~cm}$, 
primary lateral veins $1-3$ per side, usually drying darker than the lamina, departing at an angle of $40-70^{\circ}$, slightly curved towards the apex, fusing into a collective nerve 6-9 $\mathrm{mm}$ from leaf margin, second collective nerve $1-2 \mathrm{~mm}$ far from leaf margin, a little less prominent than the main collective vein; posterior divisions $2-4 \times 6-22 \mathrm{~cm}$, posterior lobes rounded, sinus up to $75 \%$ the length of the posterior divisions, acroscopic nerves 0 2 , basioscopic $2-3$. Peduncle $20-40 \mathrm{~cm}$ long, 3-4 mm diam., marbled. Spathe withish green outside, white inside, only slightly constricted at middle, $3-5(-6) \mathrm{cm}$ long, tube poorly differentiated, $1-1.5 \mathrm{~cm}$ long. Spadix unconstricted, $2-2.5 \mathrm{~cm}$ long, female portion 4-6 $\times 2-4 \mathrm{~mm}$, cylindric, fertile male portion $1,2-1,4 \mathrm{~cm}$, abruptely tappered to the apex, male flowers with 2-5-androus synandria, filaments connate, $4-5 \mathrm{~mm}$ tall, thecae square in outline, dehiscing by an apical slit (only seen in dry specimens); connectives inconspicuous; female flowers with ovoid ovary, c. $0.6-1 \times 0.6-0.8 \mathrm{~mm}, 1$-locular, ovules $3-5$, attached at the base, style conical to cylindric, c. $0.2-0.4 \times 0.1 \mathrm{~mm}$, stigma capitate. Berries subglobose to obovoid, 3$4 \mathrm{~mm}$ long, about $3 \mathrm{~mm}$ in diam., whitish grey (fide J. Bogner); seeds solitary, subglobose, 2.5-3 mm diam..

Specimens examined: BRAZIL. CEARÁ: Crato, Serra do Araripe, near Crato, above the village of Granjeiro, $850 \mathrm{~m}, 15$ 17.XI.1976, Bogner 1211 (K); Same locality, Taboleiros, 28.X.1934, Luetzelburg 25984 (US); MARANHÃO: Carolina, Estrada Carolina-Estreito, $7^{\circ} 05^{\prime} 18^{\prime \prime} \mathrm{S}-47^{\circ} 25^{\prime} 41^{\prime \prime} \mathrm{W}$, 16.I.1998, Gonçalves \& Oliveira 156 (UB); São Raimundo das Mangabeiras, 6 ${ }^{\circ} 57^{\prime} 29^{\prime \prime} \mathrm{S}$ - 4521'46"W, 18.I.1998, Gonçalves \& Oliveira 168 (UB). MATO GROSSO: Rosário Oeste, estrada Nova Brasilândia - Mazagão, ca. $65 \mathrm{~km}$ de Nova Brasilândia, 14²38'S$55^{\circ} 14^{\prime}$ W, 9.X.1997, Souza et al.20603 (ESA, UB). PIAUÍ: Floriano, proximidades de Floriano, Estrada para Canto do Buriti,
6056'06"'S-4304'28' 'W, 20.I.1998, Gonçalves \& Oliveira 172 and 182 (UB); TOCANTINS: Arraias, área ao redor do trevo para Paranã e Conceição do Tocantins, 27.XII.2000, Gonçalves 655 (UB); Arraias, estrada Arraias Paranã, $56 \mathrm{~km}$ do trevo para Conceição do Tocantins, 27.XII.2000, Gonçalves 657 (UB); Arraias, Rio Arraias, $12 \mathrm{~km}$ depois do trevo da entrada da cidade em direção à Paranã, 27.XII.2000, Gonçalves 646 (UB); Campos Belos, 8 km de Campos Belos em direção à Tabatinga, 8.X.1972, Rizzo 8443 (UFG).

Scaphispatha gracilis can be recognized by its slender inflorescences, primary lateral veins drying darker than the lamina and for the presence of lateral secondary veins as prominent as tertiary veins. It was originally described from Bolivia, but all subsequent collections were made in Brazil. Scaphispatha gracilis occurs in open woodlands ("Cerradões") and is specially common in the transition between the biomes Cerrado and Caatinga. Despite its rarity in collections, it is a common plant and is the main understory herb in some forests in Piauí state.

Scaphispatha robusta E. G. Gonç. sp. nov. Type: BRAZIL. PARÁ: Canaã dos Carajás, Morro da Torre (Morro do Sossego), $6^{\circ} 27^{\prime} 36^{\prime \prime} \mathrm{S}-50^{\circ} 04^{\prime} 28^{\prime \prime} \mathrm{W}, 21 . \mathrm{I} .2003$, Gonçalves et al. 1128 (holotype UB). Fig. 2.

A Scaphispatha gracili similis sed habitu robustiore, nervis lateralibus primariis in sicco quam lamina pallidioris, nervis lateralibus secundaris conspicue quam nervis lateralibus tertiaris prominentibus et feminea inflorescentia cum 11-15 seriebus florum manifestis lateraliter differt.

Tuberous herb, usually growing near the margins of forests, ocasionally in full sunlight. Stem tuberous, subglobose, $4 \times 3$ $\mathrm{cm}$, yellow fleshed, deeply buried in the substrate. Leaf usually solitary, ocasionally 2 or 3, erect. Petiole smooth, $29-82 \times 0.4-$ $1.2 \mathrm{~cm}$, marbled. Blade peltate, cordate to 


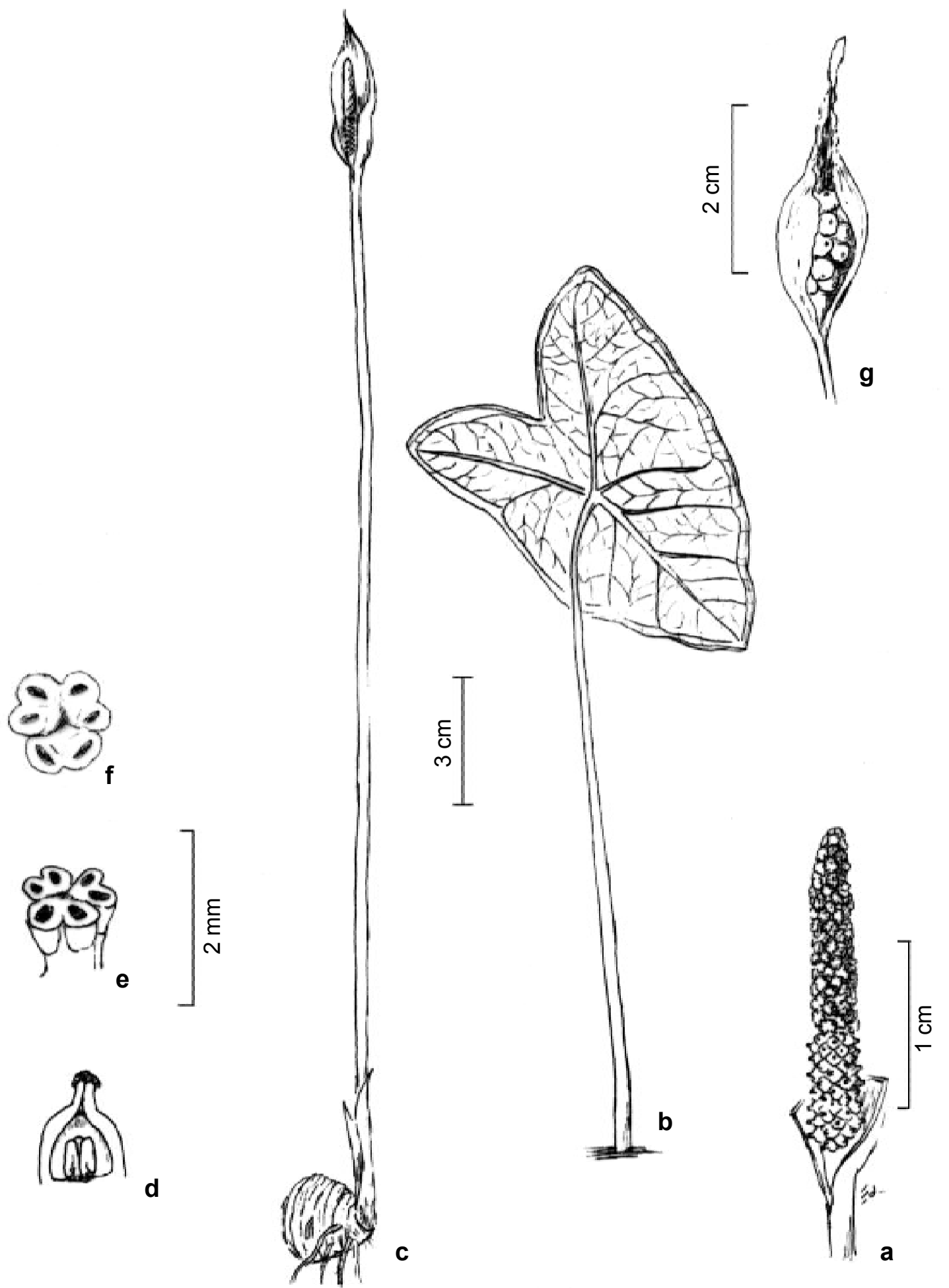

Figure 1 - Scaphispatha gracilis Brongn. ex Schott. a. Spadix (spathe removed); b. leaf; c. flowering tuber; d. ovary, longitudinal section; e. synandrium, side view; f. synandrium, upper view; g. infructescence. (a, cf, Souza 20603; b, Gonçalves 646; g, Bogner 1211 - drawn by E. G. Gonçalves) 
satigittate, ovate in outline, membranous, adaxial surface matte green, occasionally speckled in white or pale yellow, abaxial surface matte green, somewhat silvery, 14 $33 \times 11.5-27 \mathrm{~cm}$, anterior division 8-19 $\times$ $18.3-40 \mathrm{~cm}$, primary lateral veins $3-4$ per side, departing in an angle of $40-60^{\circ}$, slightly curved towards the apex, fusing in a collective nerve $8-15 \mathrm{~mm}$ from leaf margin, second collective nerve $2-5 \mathrm{~mm}$ from leaf margin, a little less prominent than the main collective nerve; posterior divisions 6-14 × 11-27 cm, posterior lobes rounded, sinus up to $65 \%$ the length of the posterior divisions, acroscopic nerves 2-3, basioscopic 2-3. Peduncle 17$25 \mathrm{~cm}$ long, 3-5 mm diam., marbled. Spathe bright green outside, whitish inside, constricted at middle, $5-7 \mathrm{~cm}$ long, tube $1.5-2 \times 3-4 \mathrm{~cm}$. Spadix 3-5 cm long, female portion $1-1.5 \times 0.5-0.7 \mathrm{~cm}$, cylindric, fertile male zone $2-3.5 \times 0.4-0.7 \mathrm{~cm}$, abrubtly tappered to the apex; male flowers with $3-$ 6-androus synandria, filaments connate, up to $1 \mathrm{~mm}$ tall, finely speckled in red, thecae whitish, somewhat square in outline, dehiscing by a " $T$ " like slit, connectives inconspicuous, grayish white; female flowers with obovoid ovary, c. $0.6-1 \times 0.8-$ $1 \mathrm{~mm}, 1$-locular, ovules 5-7, attached at the base, style conical to cylindric, c. $0.3-0.5 \times$ $0.1-0.2 \mathrm{~mm}$, stigma pale green. Berries and seeds unknown.

Paratypes: BRAZIL. GOIÁS: Mossâmedes, Reserva Ecológica da UFG em Serra Dourada, 6.XII.1999, Gonçalves et al. 367 (UB); São Miguel do Araguaia, estrada S. M. do Araguaia - Araguaçu, $13^{\circ} 10^{\prime} \mathrm{S}-50^{\circ} 01^{\prime} \mathrm{W}$, 14.II.1997, Gonçalves 81 (UB); Monte Alegre de Goiás, $3 \mathrm{~km}$ do Entron-camento com a rodovia GO-118 na GO-112 em direção a Nova Roma, 30.XII.2000, Gonçalves 693 (UB). MARANHÃO: Loreto, Estrada Buritirana - S. R.das Mangabeiras, $10 \mathrm{~km}$ de Buritirana, 11.II.1999, Lima et al. 105 (UB).
MATO GROSSO: Proximidades de Águas Quentes, $15^{\circ} 26^{\prime} 15^{\prime \prime} \mathrm{S}-59^{\circ} 06^{\prime} 26^{\prime \prime} \mathrm{W}, 487 \mathrm{~m}$, 22.I.1999, Gonçalves et al. 272 (UB). TOCANTINS: Arraias, estrada para Combinado, $28 \mathrm{~km}$ do entroncamento, 29.XII.2000, Gonçalves 681 (UB); same locality, $32 \mathrm{~km}$ do entroncamento, 29.XII.2000, Gonçalves 685 (UB); Pequizeiro, arredores da cidade, estrada para Porto Magalhães, $8^{\circ} 26^{\prime} 20^{\prime}$ 'S 4906'53'"W, 14.I.1998, Gonçalves \& Oliveira 141(UB). Without precise locality: Central Brésil, Sertão D' Amaroleite, IX-X.1844, Weddell 2849 (P).

Scaphispatha robusta differs from $S$. gracilis from its much more robust habit (see key), for the primary lateral veins that are clearer than the lamina and for the presence of lateral secondary veins conspicuously more prominent than tertiary veins. Moreover, 1115 rows of female flowers are seen in side view of inflorescences of $S$. robusta, whereas only 6-9 rows of flowers are visible in $S$. gracilis. Scaphispatha robusta has been collected mostly in central Brazil, but there are sterile collections from Acre and Rondonia states (Northwestern Brazil) that may belong to this species. It occurs along forest edges and rock outcrops, usually in moderately disturbed areas. Flowering and fruiting events in the wild are hard to observe and seem to be much faster than in other closely related genera growing in the same general area (such as Xanthosoma). In cultivation, flowering takes place at the very beginning of the rainy season (October), but all field areas visited from December to February only have both sterile adult and young specimens, whereas other aroids with similar seasonal behavior still have fruits or even occasional late inflorescences.

\section{Acknowldegments}




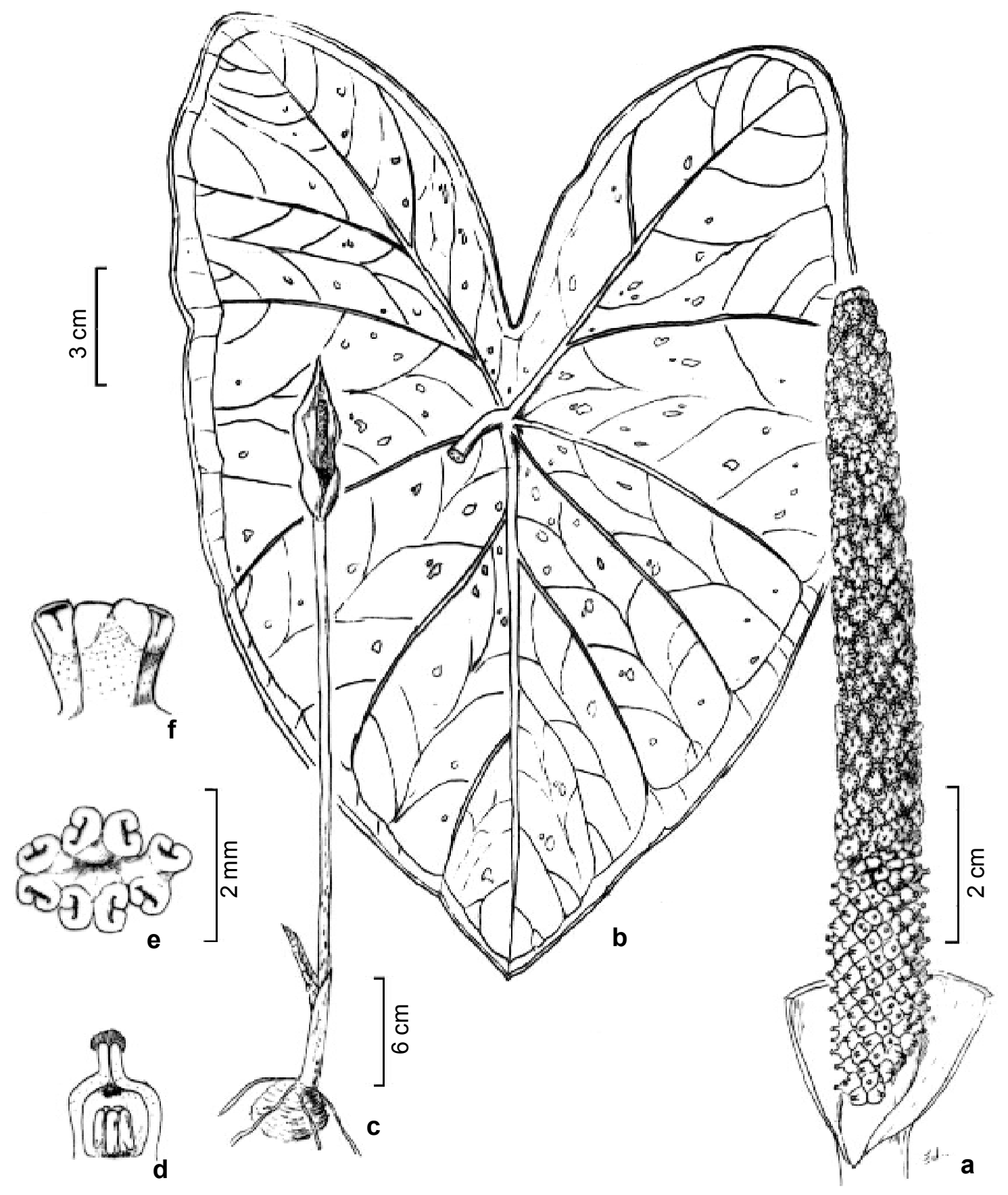

Figure 2 - Scaphispatha robusta E. G. Gonç. a. Spadix (spathe removed); b. leaf; c. flowering tuber; d. ovary, longitudinal section; e. synandrium, upper view; f. synandrium, side view. (a-f, Gonçalves 1128 drawn by E. G. Gonçalves) 
Field trips were sponsored by Instituto Plantarum de Estudos da Flora Ltda and the project "Biodiversidade do Bioma Cerrado" (EMBRAPA, UnB, ISPN, DFID). Observations on European herbaria were sponsored by Fundação Botânica Margaret Mee.

\section{Literature Cited}

Bogner, J. 1980. The genus Scaphispatha Brongn. ex Schott. Aroideana 3:4-12.

French, J. C.; Chung, M. G. \& Jur, Y. K. 1995. Chloroplast DNA phylogeny of the Ariflorae. Pp. 225-275, in Rudall, P. J.; Cribb, P. J. \& Cuttler, D. F. (ed.). Monocotyledons: Systematics and Evolution. Royal Botanic Gardens, Kew.

Gonçalves, E. G. 2004. Araceae from Central Brazil: Comments on their Diversity and Biogeography. Annals of the Missouri Botanical Garden 91:457-463.

Keating, R. C. 2004. Vegetative anatomical data and its relationship to a revised classification of the genera of Araceae. Annals of the Missouri Botanical Garden 91: 485-494.

Mayo, S. J.; Bogner, J. \& Boyce, P. C. 1997. The Genera of Araceae. Royal Botanic Gardens, Kew.

Schott, H. W. 1860. Prodromus systematis aroidearum. Congretationis Mechitharisticae, Vindobonae.

\section{Notes Added in Proofs}

In early November of 2005, two cultivated specimens of Scaphispatha robusta (Gonçalves 681) produced inflorescences that opened in two consecutive days. I was able to observe their flowering behavior and hand-pollinate the younger inflorescence. The spathe opens in a peculiar fashion considering most tube-forming inflorescences in the Caladieae. In Scaphispatha, the spathe starts to open at the proximal region, i.e., near the female flowers. It occurs during the female phase, when stigmas are wet, so the pollinators (unknown) probably climb the peduncle coming from the soil rather than land from flight. During the second day the spathe also unfurl distally and acquire the conformation of a boat (hence the name Scaphispatha). At the end of the second day of anthesis the spathe usually fold back and expose almost completely the male spadix, which is shedding the pollen grains in threads. In the third day, the spathe come back to the erect position and the distal part (spathe lamina) starts to get marcescent, whereas the proximal portion (spathe tube) closes once again and is kept like this until the ripening of berries. The interval between the anthesis and the dehiscence of berries was exactly 40 days. When berries are ripe, the spathe tube split and dehisces at base and the berries fall off. In the floor, the white pericarp turns into a blackish and slimy cover that soon exposes the brown testa with a white strophiole formed by the funicle. The presence of this structure suggests the dispersion by ants. The description of berries and seeds is given below:

Berries subglobose to barrel-shaped, 4$6 \mathrm{~mm}$ long, 3-6 $\mathrm{mm}$ in diameter, whitish grey or slightly lavender, pericarp somewhat spongy; seeds solitary, rarely two, ovoid, 3-4 $\mathrm{mm}$ long, 4-5 $\mathrm{mm}$ in diam., testa thin and smooth, brown, funicle forming a white strophiole, endosperm copious, embryo small, straight, greenish. 
